\title{
41. CONSOLIDATION AND STRENGTH OF PLIOCENE-PLEISTOCENE SEDIMENTS FROM SITES 646 AND 647, ODP LEG 105
}

\author{
Kathleen A. Dadey² and Armand J. Silva ${ }^{3}$
}

\begin{abstract}
Based on laboratory geotechnical tests, the stress history of sediment drift deposits at two Ocean Drilling Program (ODP) sites of Leg 105 is analyzed. Geological analyses of Sites 646 and 647 indicate that sedimentation is primarily controlled by bottom currents having periodic turbidite sequences and no significant hiatuses. Consolidation tests on a limited number of good quality subsamples and other supporting data show that sediments deeper than approximately 5 to at least 150 meters below seafloor (mbsf) are significantly underconsolidated (i.e., these sediments are still consolidating under the existing overburden stresses) and have overconsolidation ratios of less than 0.4 below 50 mbsf. Possible explanations for this underconsolidation include relatively high rates of sedimentation (up to $80 \mathrm{~m} / \mathrm{m}$.y.), low permeability layers, an upper zone $(\sim 5 \mathrm{~m})$ of apparently overconsolidated sediment, high concentrations of siliceous microfossils, and the existence of nonlinear flow behavior at low hydraulic gradients.
\end{abstract}

\section{INTRODUCTION AND GEOLOGIC SETTING}

To some extent, sedimentary deposits "remember" stresses borne in the past. Investigation of this phenomenon, referred to as stress history, can yield valuable information pertaining to depositional and post-depositional processes. For example, an overconsolidated sediment is interpreted as having previously sustained an overburden stress greater than that of today. This situation can result by removing the overburden, which is usually caused by erosion or mass wasting processes. On the other hand, an underconsolidated sediment indicates that the deposit is experiencing excess pore water pressures and has not yet consolidated under its present stress. Causes include extremely rapid sedimentation and other phenomena that hinder the normal expulsion of pore fluids during consolidation. A normally consolidated state, which implies complete dissipation of pore water pressures, is associated with steady sedimentation and complete consolidation under the present overburden stress.

This research determines the stress history of Pliocene-Pleistocene sediments at two sites recovered during ODP Leg 105. Site $646\left(58^{\circ} 12.56^{\prime} \mathrm{N}, 48^{\circ} 22.15^{\prime} \mathrm{W}\right.$; water depth of $\left.3451 \mathrm{~m}\right)$ is located on the northern flank of the Eirik Ridge, a drift (contourite) deposit south of Greenland. Site $647\left(53^{\circ} 19.88^{\prime} \mathrm{N}\right.$, $45^{\circ} 15.72^{\prime} \mathrm{W}$; water depth of $3862 \mathrm{~m}$ ) is located on the southern flank of Gloria Drift (Fig. 1).

Almost the entire sedimentary sequence at Site 646 was reported as having been deposited or reworked by bottom currents (Srivastava, Arthur, et al., 1987). Although thin layers of turbidites were observed in Subunit IA (0-188 mbsf), sedimentation was described as continuous (Srivastava, Arthur, et al., 1987). Sedimentation rates in the Pliocene-Pleistocene Subunit IA average $79 \mathrm{~m} / \mathrm{m}$.y. Ice-rafted debris is common to abundant in lithologic Unit I (0-236 mbsf). Sediments are terrigenous, with variable amounts of biogenic material, up to $40 \%$ to $50 \%$ throughout the recovered sequence.

The upper $100 \mathrm{~m}$ of sediment at Site 647 is part of the Gloria Drift contourite deposit. Turbidite layers are present in Unit I

\footnotetext{
${ }^{1}$ Srivastava, S. P., Arthur, M., Clement, B., et al., 1989. Proc. ODP, Sci. Results, 105: College Station, TX (Ocean Drilling Program).

${ }^{2}$ Graduate School of Oceanography, University of Rhode Island, Narragansett, RI 02882.

3 Department of Ocean Engineering, University of Rhode Island, Kingston, RI 02881 .
}

(0-116 mbsf), but deposition processes are dominated by bottom currents. Much of Unit I is bioturbated, and sedimentation rates average $46 \mathrm{~m} / \mathrm{m} . y$. (Srivastava, Arthur, et al., 1987). Sediments consist mainly of fine-grained terrigenous debris, with biogenic contents in one minor facies that reach $40 \%$ to $50 \%$. Icerafted material is important throughout Unit I (Srivastava, Arthur, et al., 1987).

Preliminary geological analyses of these holes suggest that Pliocene-Pleistocene sedimentation at both sites is controlled mainly by bottom-current activity and periodic turbidite spillover from the Northwest Atlantic Mid-Ocean Channel (NAMOC). Although deposition is somewhat sporadic, the absence of major hiatuses suggests a lack of significant erosion in the Pliocene-Pleistocene sections at either site (Srivastava, Arthur, et al., 1987). As a result, deposits should be normally to slightly overconsolidated.

\section{METHODS}

Whole-round samples having as little disturbance as possible were obtained from the ends of core sections. Specimens were chosen from sections near the center of individual cores to reduce the possibility of flow-in disturbance. Post-sampling changes were minimized by coating specimens with wax and refrigerating them. Samples were then handcarried back to the University of Rhode Island, where they were stored at $4^{\circ} \mathrm{C}$, submerged in seawater until testing.

Consolidation testing (e.g., Am. Soc. Testing Materials, 1987) generates a plot of void ratio $(e)$ vs. logarithm effective stress $\left(\sigma^{\prime}\right)$ that exhibits a characteristic shape. Certain parameters can be obtained from this curve based on theoretical and empirical considerations (Lambe and Whitman, 1969).

Casagrande's method (1936) was applied to the void ratio vs. logarithm effective stress $\left(e \log \sigma^{\prime}\right)$ curves to estimate the preconsolidation stresses. Overburden vs. depth relationships were developed from bulk density data obtained on board ship (Srivastava, Arthur, et al., 1987). The overconsolidation ratio (OCR) was calculated as the ratio of preconsolidation stress to overburden stress. Samples displaying OCRs above 1.2 are considered overconsolidated, whereas those having OCRs of less than about 0.7 are underconsolidated. OCRs that range between 0.7 and 1.2 imply normal consolidation.

The compression index $\left(C_{c}\right)$ was determined as the slope of the virgin consolidation curve the portion beyond the "knee," which represents the compressibility of the material in the field. The coefficient of permeability (hydraulic conductivity) was determined from consolidation data using the square root of time (Taylor, 1948) and the logarithm of time (Casagrande, 1936) methods. Reported permeability values are extrapolated to the void ratio at the preconsolidation stress. 


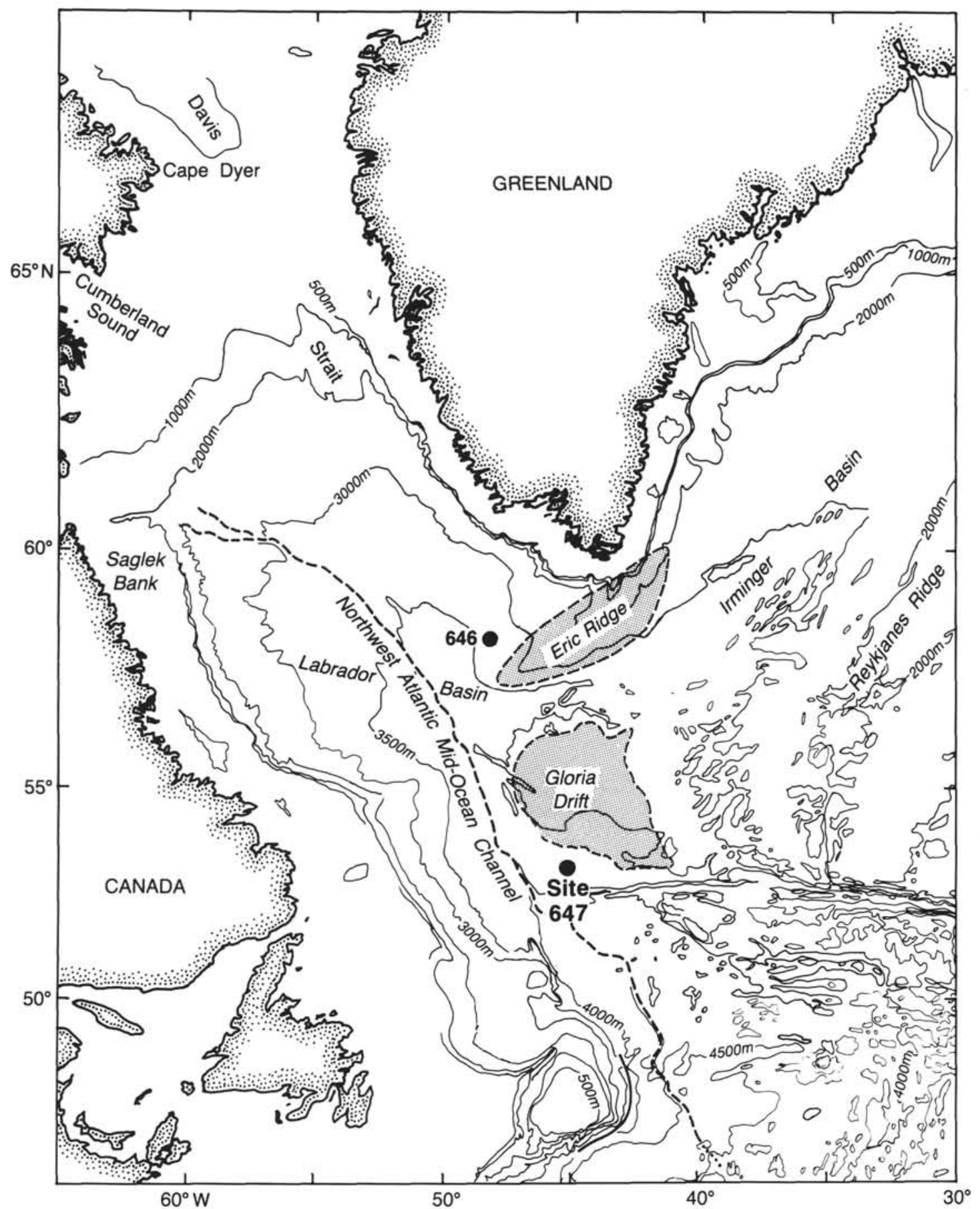

Figure 1. Base map showing ODP Sites 646 and 647.

Equipment, methods and procedures used to obtain shipboard data may be found in the "Explanatory Notes" chapter of Srivastava, Arthur, et al. (1987).

\section{INDEX PROPERTY DATA}

In general, index properties at Sites 646 and 647 follow trends similar to those described for other marine sediments (e.g., Bryant et al., 1981). Porosity decreases steadily with depth to approximately 70 mbsf at each site (Fig. 2 and 3). Below 70 mbsf, porosity values display little change with depth throughout the remainder of the APC-cored interval. An increase in the baseline porosity below $150 \mathrm{mbsf}$ in Hole $646 \mathrm{~B}$ may be related to disturbance caused by extended-core-barrel (XCB) drilling.
The disturbance generated by $\mathrm{XCB}$ drilling is visible in the shear-strength profile of Hole 646B. Shear-strength values decrease sharply in the XCB-recovered zone below 130 mbsf. Shear strength can be a sensitive indicator of other types of coring disturbance as well. Other zones of low shear strength (e.g., $74-83 \mathrm{mbsf}$ in Hole 646A and $85-100$ mbsf in Hole 646B) correlate with regions of coring disturbance (Srivastava, Arthur, et al., 1987).

Aside from the variability caused by coring disturbances, shear strengths exhibit a general increase with depth at both sites. The rate of increase is slightly higher in Hole 647B, where sedimentation rates are lower. This trend is consistent with the relationship of strength and sedimentation rate reported by Bryant and Trabant (1972). 
In addition, an upper layer from the surface to approximately $10 \mathrm{mbsf}$, in which the properties essentially do not vary, exists at each site. This upper zone corresponds to the apparently overconsolidated (AOC) layer discussed below. The existence of an AOC layer also is indicated by the plot of the ratio of shear strength to overburden stress vs. depth (Figs. $2 \mathrm{C}$ and $3 \mathrm{C}$ ). The upper 5 to $10 \mathrm{~m}$ at each site is characterized by shear strength/overburden $\left(S_{u} \sigma^{\prime}{ }_{o}\right)$ ratios that exceed 0.4 . Richards and Hamilton (1967) reported that normally consolidated samples generally exhibit ratios of 0.2 to 0.4 .

\section{COMPRESSIBILITY AND STRESS HISTORY DATA}

The results of successful consolidation testing and permeability analyses are summarized in Table 1 . Two samples from $75.37 \mathrm{mbsf}$ at Site 646 were tested because the first sample retrieved at this depth, in Hole 646A, was in a flow-in region.

Various problems with laboratory equipment resulted in anomalous data, particularly a divergence from the typical $e \log \sigma^{\prime}$ plots. Only data from successful tests are included here (Table 1). Several $e \log \sigma^{\prime}$ plots displayed in Figures 4 through 9 are representative of the samples discussed here.

Based on the results from these curves, all samples except the one at 4.47 mbsf in Hole 646A (Fig. 4) are moderately to significantly underconsolidated (Table 1). The higher OCR value at $4.47 \mathrm{mbsf}$ is attributed to apparent overconsolidation, which has been found in the upper few meters of essentially all deepsea clays (e.g., Silva and Jordan, 1984; Richards and Hamilton, 1967). The phenomenon of apparent overconsolidation has been attributed to the high inherent strength of the deposit relative to the overburden stress at shallow depths. The normal consolidation process is hindered in this layer (Silva et al., 1976), which results in an upper layer of invariant porosity and shear strength.

Although underconsolidation is not uncommon in the deep sea (Bryant et al., 1981), the large percentage of extremely underconsolidated $(O C R<0.5)$ samples in this data set is particularly intriguing. One possible explanation for this type of anomalous behavior is sample disturbance. Numerous factors, including coring, subsampling, and handling can disrupt the structure of marine sediments, leading to a reduction in measured shear strength, preconsolidation stress, and, consequently, overconsolidation ratio. Coring disturbance, although a serious problem in rotary drilled holes (e.g., Bennett and Keller, 1973), is much less common in sequences recovered by hydraulic piston coring (Mayer, 1982).

All but two of the samples studied were recovered using the advanced hydraulic piston coring (APC) system (Table 1). Based on visual core descriptions in Srivastava, Arthur, et al. (1987) and shear-strength profiles, the only samples in the APC-cored zone that were suspected of sustaining a significant degree of disturbance from coring occur at 75.37 mbsf in Hole 646A (Fig. 5) and at 96.47 mbsf in Hole 646B. The first sample is from a region of flow-in detected visually in the split core section and evidenced by low shear-strength values (Fig. 2). The low shear strength in the interval between 85 and 100 mbsf in Hole 646B also indicates that the sample at $96.47 \mathrm{mbsf}$ is disturbed. The two samples recovered using XCB drilling display $e \log \sigma^{\prime}$ plots indicative of disturbance (Fig. 6), probably the result of the drilling process. Significantly lower shear strengths in the XCB interval below $130 \mathrm{mbsf}$ in Hole 646B support this hypothesis (Fig. 2).

Consequently, based on the available data, shear-strength profiles, and visual core descriptions, we do not believe that the majority of these samples experienced the degree of disturbance necessary to produce such low OCRs. We must conclude that below about 5 mbsf, these deposits are truly underconsolidated, experience excess pore pressures, and have not yet reached equilibrium with the overburden, at least to depths of about 125 mbsf. Below 125 mbsf, disturbance caused by XCB drilling casts doubt on the accuracy of the consolidation data. Ratios of shear strength to overburden (Figs. 2 and 3 ) fall well below the range of 0.2 to 0.4 specified as normally consolidated by Richards and Hamilton (1967). These data are consistent with an underconsolidated state.

Sangrey (1977) examined a number of mechanisms that may be responsible for underconsolidation in marine sediments. One of the most common causes is a rapid rate of deposition, which has been described extensively in the Gulf of Mexico (e.g., Morgenstern, 1967). However, although sedimentation rates at Sites 646 and 647 are relatively high for the deep sea $(<80 \mathrm{~m} /$ m.y.), they are lower than those required to produce underconsolidation of the magnitude measured.

Sangrey also reported that gas formed in situ as organic matter decomposes may produce underconsolidation because of excess pore pressure. Organic contents of these Labrador Sea cores are low and rarely exceed $0.5 \%$ (Srivastava, Arthur, et al., 1987). This fact, coupled with low to nonexistent quantities of methane gas, leads us to believe that gas production does not contribute significantly to the underconsolidation of these deposits.

Upward fluid advection, which also generates excess pore pressures, may result in underconsolidation as well (Sangrey, 1977). However, heat flow studies at shallow depths around the region and to 93 mbsf in Hole 646A do not indicate fluid flow (Louden et al., this volume).

Bryant et al. (1981) described undisturbed sediments from the Japan Trench, which displayed underconsolidation despite geological evidence indicating normally consolidated conditions. The authors' explanation for the low OCRs was the presence of diatoms in quantities of approximately $30 \%$, which formed a rigid framework that resisted compression but was sensitive to shock. This structure broke down during coring and produced anomalous consolidation results. Siliceous microfossils are present at Sites 646 and 647, but never in as high concentrations (Srivastava, Arthur, et al., 1987) as described by Bryant et al. (1981). Nevertheless, their presence may be a contributing factor in the underconsolidated condition.

Silva et al. (1976) reported significant underconsolidation in samples from the East Bermuda Rise, a drift deposit in the Western North Atlantic, the Sohm Abyssal Plain (Silva and Jordan, 1984), and the Southern Nares Abyssal Plain (Silva and Mairs, 1987). Silva et al. (1976) attributed the underconsolidation to a combination of several factors. These included a "cap" of apparently overconsolidated sediment that increases the drainage path, very low permeability strata, and intermediate layers with high rates of sedimentation. Furthermore, flow behavior at very low hydraulic gradients may be nonlinear or flow may not occur until a certain threshold gradient is reached (Olsen, 1965). These effects cannot be adequately assessed owing to limited samples and data; thus, they may possibly contribute to the low OCRs of these Leg 105 samples.

Richards (1984) stated that excess pore pressures and underconsolidation are the rule in cohesive marine sediments because of the low permeability of such deposits. Permeabilities determined for these Leg 105 sediments are relatively high, compared with reported averages (Bryant et al., 1981) and values predicted from empirical equations (Bryant et al., 1974). Nevertheless, they probably contribute to the low OCRs, particularly when combined with the relatively rapid sedimentation rates.

\section{CONCLUSIONS}

The results of consolidation testing of samples at Sites 646 and 647 of Leg 105, however limited, suggest that these sediments are significantly underconsolidated below approximately 5 mbsf. Based on the available data, we believe that this under- 


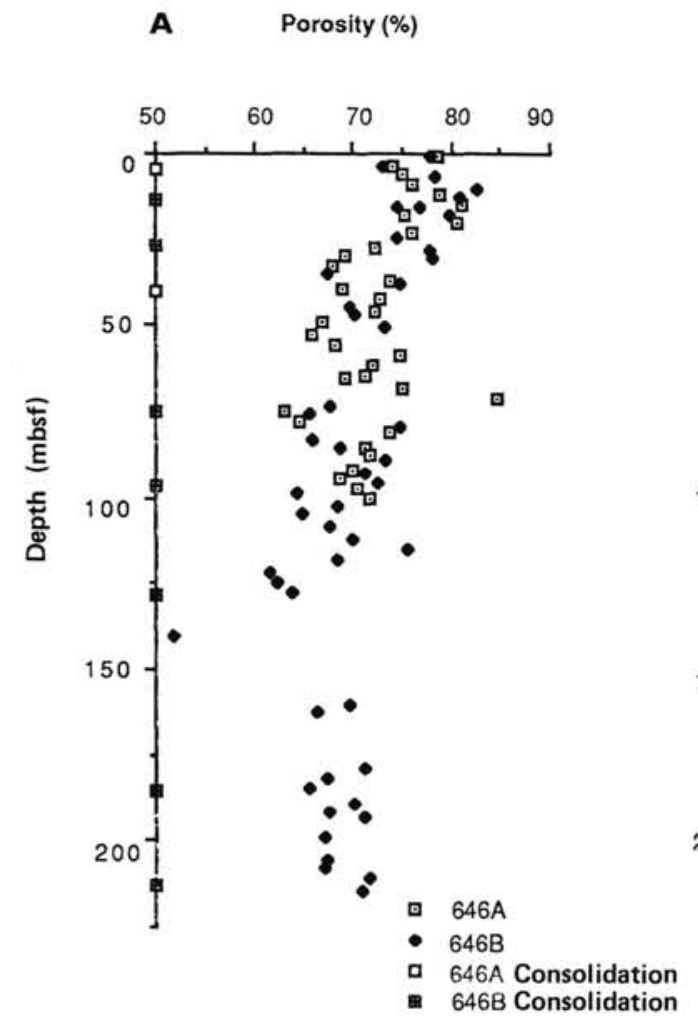

B Shear Strength $(\mathrm{kPa})$

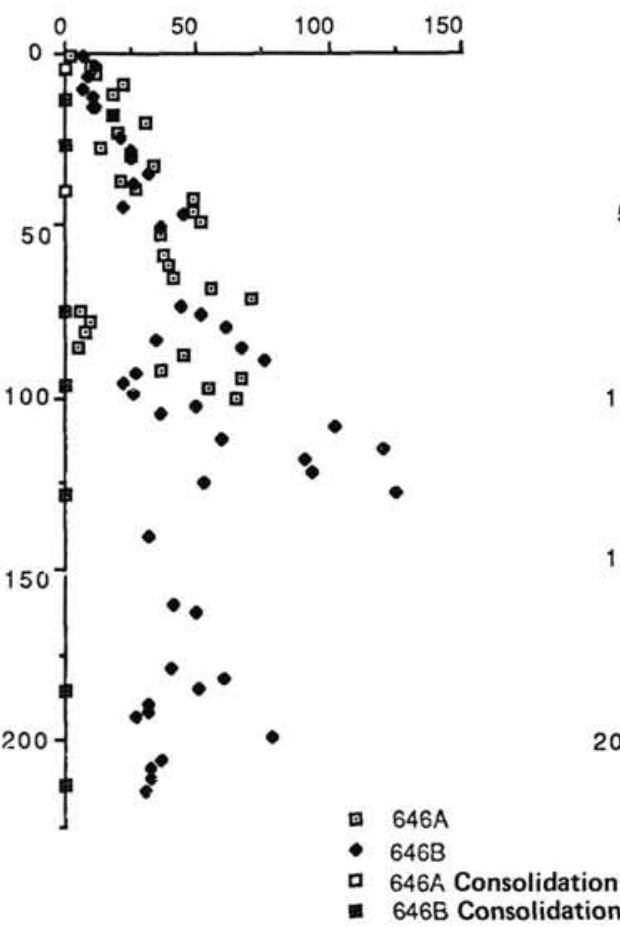

C Shear Strength/Overburden ratio

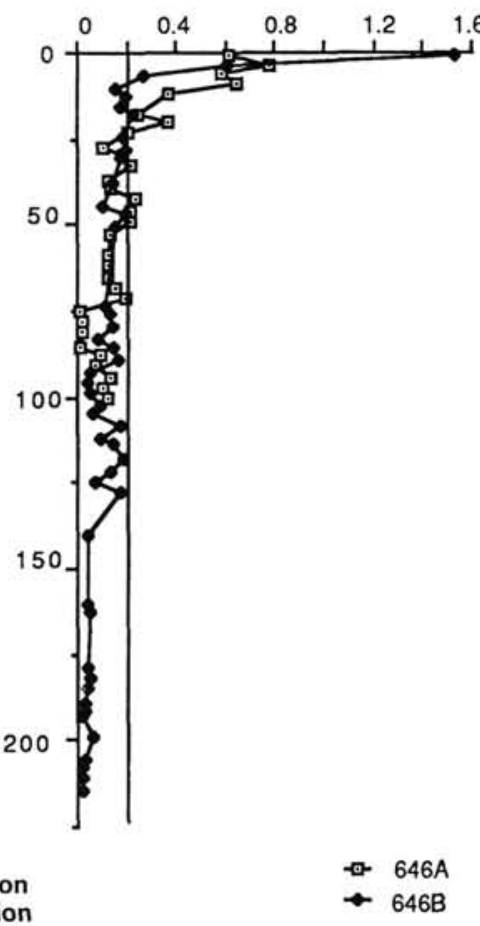

Figure 2. Index-property profiles for Holes 646A and 646B from shipboard measurements. Depths of consolidation samples are indicated on the ordinate in A and B. The vertical line in C marks the lower limit of "normal consolidation" based on Richards and Hamilton (1974).

A Porosity (\%)

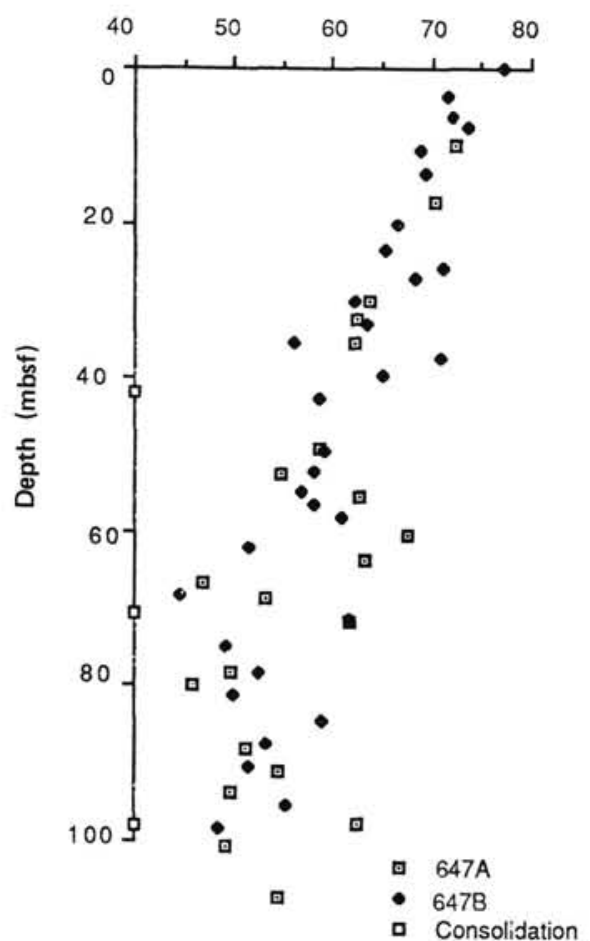

B Shear Strength $(\mathrm{kPa})$

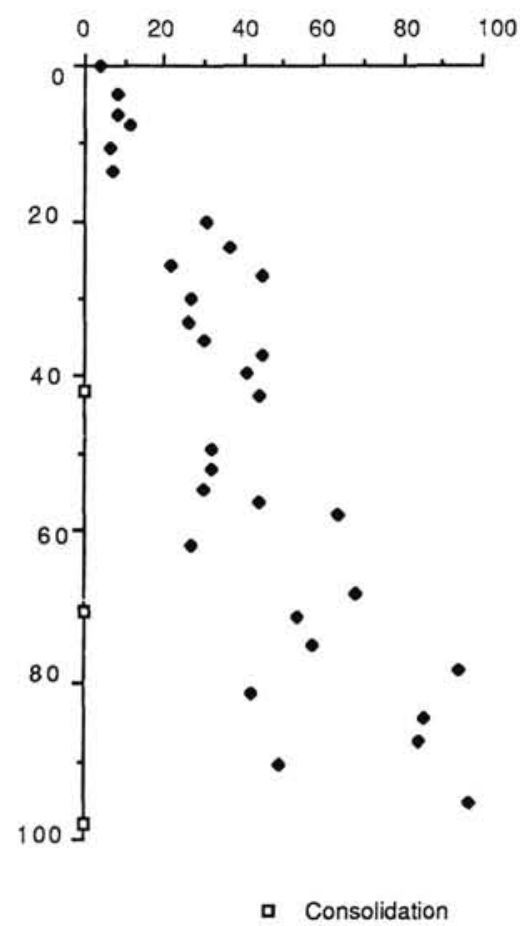

C Shear Strength/Overburden ratio

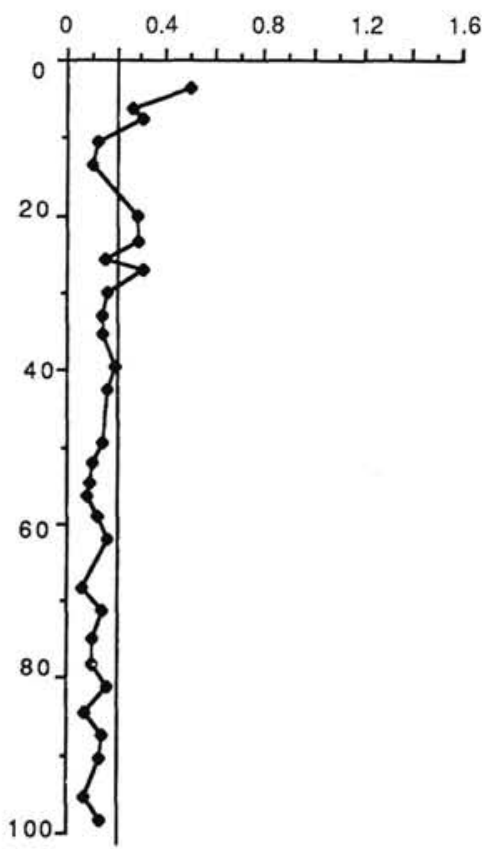

Figure 3. Index-property profiles for Holes 647A and 647B from shipboard measurements. Depths of consolidation samples are indicated on the ordinate in A and B. Shear-strength measurements from Hole 647A are omitted from B because disturbance caused by rotary drilling results in anomalous values (see text). The vertical line in C marks the lower limit of "normal consolidation" based on Richards and Hamilton (1974). 
Table 1. Summary of laboratory results.

\begin{tabular}{|c|c|c|c|c|c|c|c|c|}
\hline Hole & $\begin{array}{l}\text { Depth } \\
\text { (mbsf) }\end{array}$ & $\begin{array}{c}\sigma_{o}^{\prime} \\
(\mathrm{kPa})\end{array}$ & $\begin{array}{c}\sigma_{c}^{\prime} \\
(\mathrm{kPa})\end{array}$ & OCR & $C_{c}$ & $\begin{array}{c}k \\
(\mathrm{~cm} / \mathrm{s})\end{array}$ & $\begin{array}{c}S_{u} \\
(\mathrm{kPa})\end{array}$ & Sample quality* \\
\hline \multirow[t]{3}{*}{$646 \mathrm{~A}$} & 4.47 & 14.8 & 34.3 & 2.31 & 1.1 & $6 \cdot 10^{-7}$ & 10 & Good \\
\hline & 40.27 & 195.0 & 93.2 & 0.84 & 0.8 & $1.5 \cdot 10^{-6}$ & 27 & Fair \\
\hline & 75.37 & 394.5 & 30.4 & 0.08 & 0.65 & $2.2 \cdot 10^{-7}$ & 6 & Very good (flow-in) \\
\hline \multirow[t]{7}{*}{$646 \mathrm{~B}$} & 13.47 & 55.4 & 14.7 & 0.26 & 0.24 & $8 \cdot 10^{-7}$ & 11 & Somewhat disturbed \\
\hline & 27.07 & 125.1 & 70.6 & 0.56 & 0.94 & $6.5 \cdot 10^{-7}$ & 25 & Very good \\
\hline & 75.37 & 395.0 & 98.1 & 0.25 & 0.68 & $6 \cdot 10^{-6}$ & 50 & Good \\
\hline & 96.47 & 527.5 & 37.3 & 0.07 & 0.4 & $1 \cdot 10^{-6}$ & 24 & Very good (coring disturbance) \\
\hline & 128.27 & 731.7 & 256.2 & 0.35 & 0.57 & - & 125 & Fair \\
\hline & 185.97 & 1144.5 & 68.9 & 0.06 & 0.29 & - & 51 & Disturbed (XCB drilled) \\
\hline & 213.47 & 1323.4 & 196.2 & 0.15 & 0.54 & $2 \cdot 10^{-6}$ & 33 & Disturbed (XCB drilled) \\
\hline \multirow[t]{3}{*}{$647 \mathrm{~B}$} & 41.77 & 245.5 & 78.5 & 0.32 & 0.39 & $1 \cdot 10^{-7}$ & 42 & Fair \\
\hline & 70.67 & 478.7 & 127.5 & 0.27 & 0.48 & $6 \cdot 10^{-7}$ & 67 & Fair \\
\hline & 97.97 & 706.3 & 127.5 & 0.18 & 0.28 & $5.5 \cdot 10^{-7}$ & 96 & Good \\
\hline
\end{tabular}

*Sample quality based on appearance of $e \log \sigma^{\prime}$ curve; additional comments in parentheses. $\sigma_{o}^{\prime}=$ overburden stress; $\sigma_{c}^{\prime}=$ preconsolidation stress; $\mathrm{OCR}=$ overconsolidation ratio; $C_{c}=$ compression index, $k=$ coefficient of permeability; $S_{u}=$ undrained shear strength.

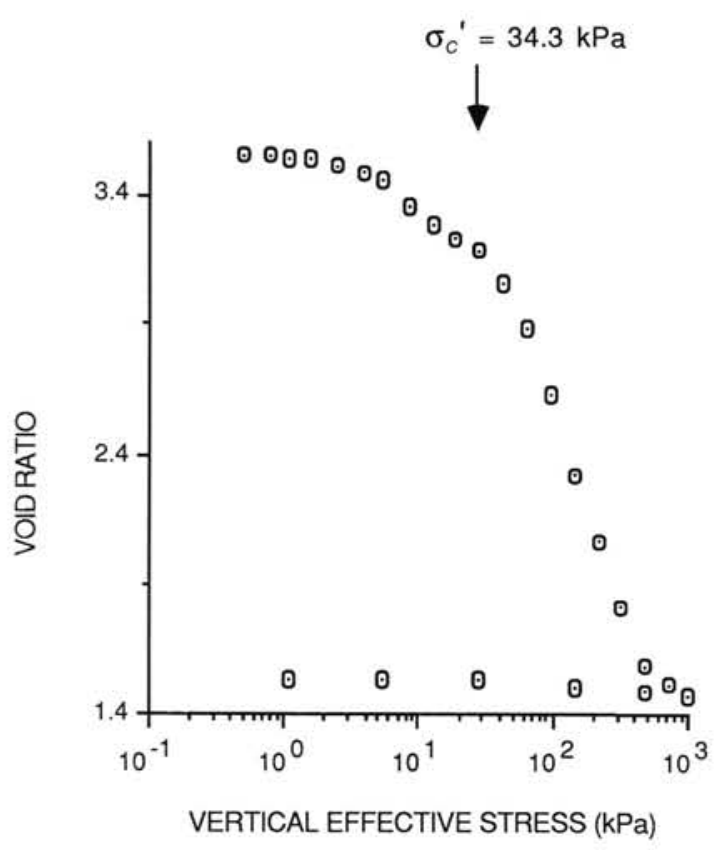

Figure 4. Void ratio vs. logarithm effective stress; Hole 646A, 4.47 mbsf.

consolidation problably results from a combination of factors, including (1) relatively high sedimentation rates and low permeability that impede the dissipation of excess pore pressures, (2) high concentrations of siliceous microfossils, (3) an upper zone $(\sim 5 \mathrm{~m})$ of apparently overconsolidated sediment, and (4) the existence of nonlinear flow behavior at very low gradients.

Future research should be aimed at resolving the question of underconsolidation that is evident in many deep-sea sediments. Additional consolidation testing of high-quality deep-sea samples (deeper than $20 \mathrm{~m}$ ) is needed to delineate the extent of underconsolidation in this and other areas of the world ocean. Associated in-situ pore pressure measurements at depth to verify the state of stress also should be conducted. Analytical modeling efforts should incorporate all the variables that may contribute to the underconsolidation phenomenon.

\section{REFERENCES}

American Society for Testing and Materials, 1987. Annual Book of ASTM Standards, Natural Building Stones, Soil and Rock: Philadel-

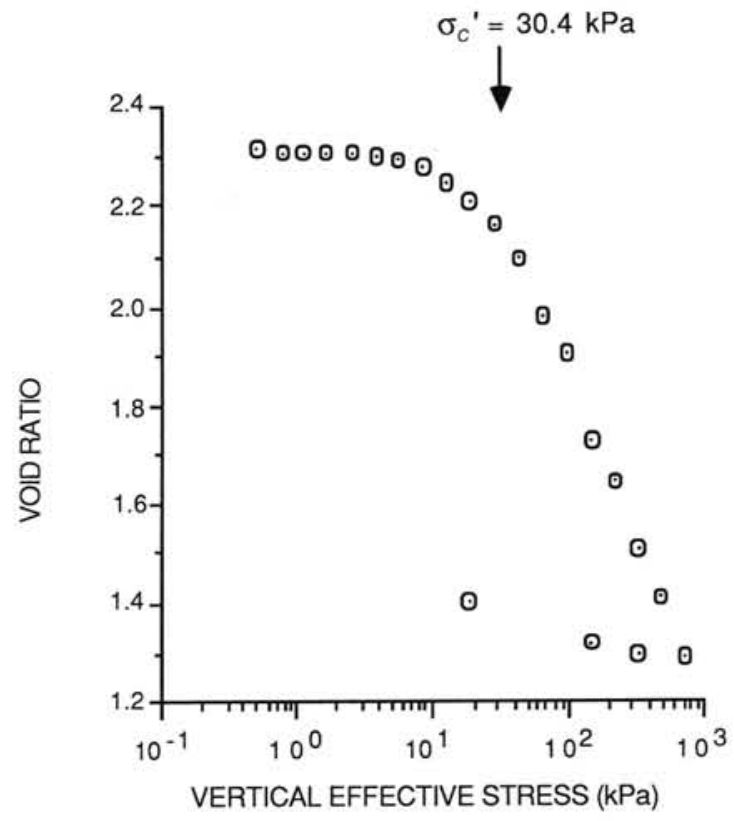

Figure 5. Void ratio vs. logarithm effective stress; Hole 646A, 75.37 mbsf.

phia (Am. Soc. Testing Materials).

Bennett, R. H., and Keller, G. H., 1973. Physical properties evaluation. In van Andel, T. H., Heath, G. R., et al., Init. Repts. DSDP, 16; Washington (U.S. Govt. Printing Office), 513-519.

Bryant, W. R., and Trabant, P. K., 1972. Statistical relationships between geotechnical properties of Gulf of Mexico sediments. Proc. 4th Annual Offshore Tech. Conf., Preprints II, 363-368.

Bryant, W. R., Deflache, A. D., and Trabant, P. K., 1974. Consolidation of marine clays and carbonates. In Interbitzen, A. (Ed.), Deep Sea Sediments Physical and Mechanical Properties: New York (Plenum Press), 209-244.

Bryant, W. R., Bennett, R. H., and Katherman, C. E., 1981. Shear strength, consolidation, porosity, and permeability of oceanic sediments. In Emiliani, C. (Ed.) The Oceanic Lithosphere: The Sea, Vol. 7: New York (Wiley \& Sons), 1555-1616.

Casagrande, A., 1936. The determination of the pre-consolidation load and its practical significance. Proc. Int. Conf. Soil Mechanics III: Cambridge (Harvard Univ.), 60.

Lambe, T. N., and Whitman, R. V., 1969. Soil Mechanics: New York (Wiley).

Mayer, L. A., 1982. Physical properties of sediment recovered on Deep 
Sea Drilling Project Leg 68 with the hydraulic piston corer. In Prell, W. L., Gardner, J. V., et al., Init. Repts. DSDP, 68: Washington (U.S. Govt. Printing Office), 365-371.

Morgenstern, N. R., 1967. Submarine slumping and the initiation of turbidity currents. In Richards, A. (Ed.), Marine Geotechnique: Chicago (Univ. of Illinois Press), 189-220.

Olsen, Harold, W., 1965. Deviations from Darcy's Law in saturated clays. Proc. Soil Sci. Soc. Am., 29:135-140.

Richards, A. F., 1984. Introduction modeling and the consolidation of marine soils. In Denness, B. (Ed.), Seabed Mechanics: London (Graham and Trotman, Ltd.), 3-8.

Richards, A. F., and Hamilton, E. L., 1967. Investigations of deep-sea sediment cores, III: consolidation. In Richards, A. (Ed.), Marine Geotechnique: Chicago (Univ. of Illinois Press), 93-117.

Sangrey, D., 1977. Marine geotechnology-state of the art. Mar. Geotechnol., 2:45-80.

Silva, A. J., Hollister, C. D., Laine, E. P., and Beverly, B., 1976. Geo-

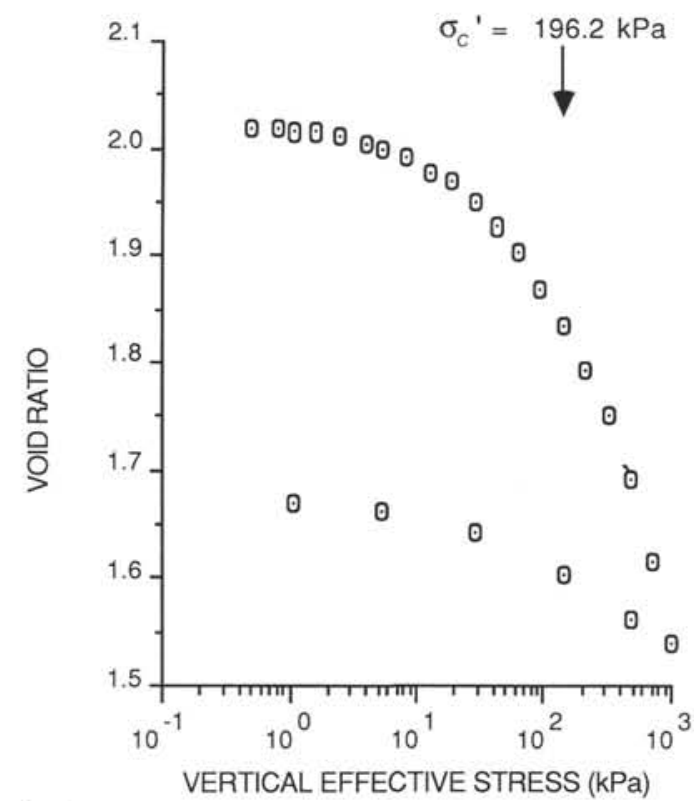

Figure 6. Void ratio vs. logarithm effective stress; Hole 646B, 213.17 mbsf.

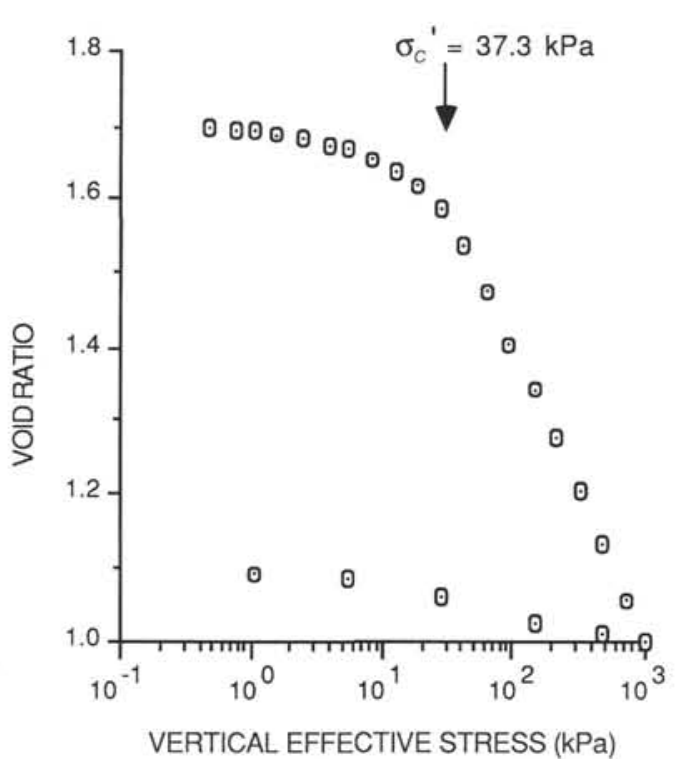

Figure 8. Void ratio vs. logarithm effective stress; Hole 646B, 96.47 mbsf. technical properties of deep-sea sediments: Bermuda Rise. Mar. Geotechnol., 1:195-232.

Silva, A. J., and Jordan, S., 1984. Consolidation properties and stress history of some deep-sea sediments. In Denness, B. (Ed.), Seabed Mechanics: London (Graham and Trotman, Ltd.), 25-39.

Silva, A. J., and Mairs, H., 1987. Stress History and Geotechnical Properties of Nares and Madeira Abyssal Plain Sediments: Narragansett, RI (Univ. of Rhode Island), Tech. Rept. 161.

Srivastava, S., Arthur, M. A., et al., 1987. Proc. ODP, Init. Repts., 105: College Station, TX (Ocean Drilling Program).

Taylor, D. W., 1948. Fundamentals of Soil Mechanics: New York (Wiley \& Sons, Inc.).

Date of initial receipt: 21 December 1987

Date of acceptance: 1 August 1988

Ms 105B-145

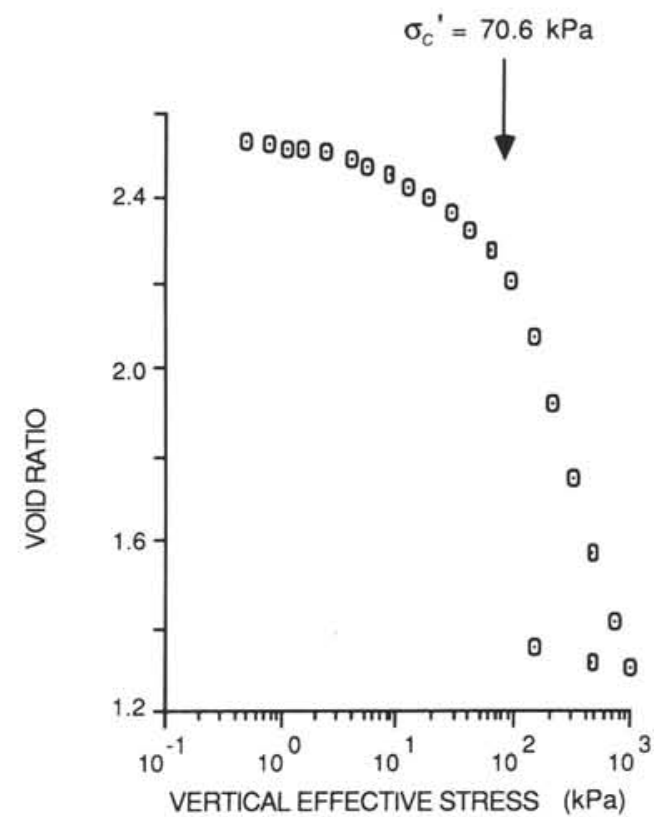

Figure 7. Void ratio vs. logarithm effective stress; Hole 646B, 27.07 mbsf.

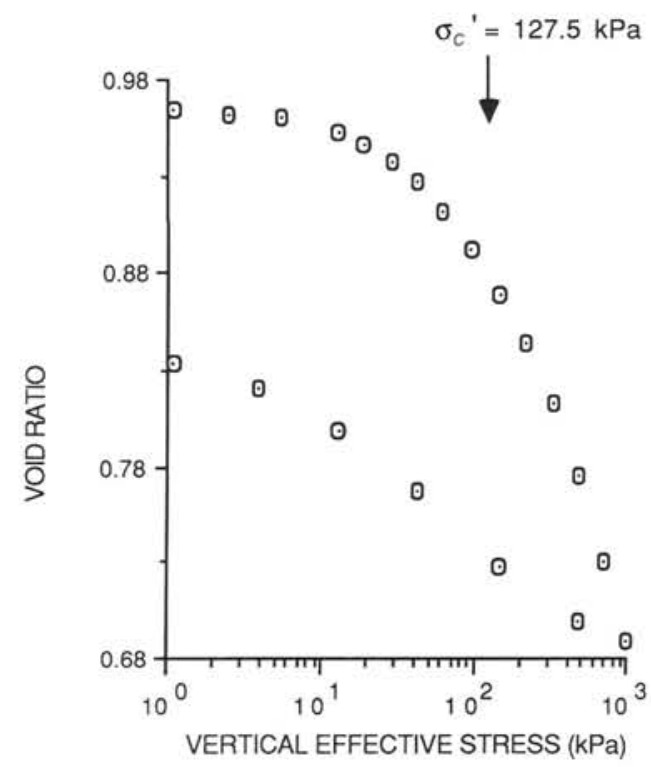

Figure 9. Void ratio vs. logarithm effective stress; Hole 647B, 96.97 mbsf. 